\title{
Arbuscular mycorrhizal association and dependency determined the pioneer plant community, diversity structure and plant cover in two river bank under same climate
}

\author{
Somdatta Ghosh ${ }^{1}$,* D. Kuila ${ }^{1}$ and N. K. Verma ${ }^{2}$ \\ ${ }^{1}$ Department of Botany. Midnapore College. Midnapur-721101. W. B. India. Email: \\ somdattaghosh@yahoo.co.in. \\ ${ }^{2}$ Department of Botany. Vidyasagar University. Midnapur-721102. W. B. India.
}

\begin{abstract}
Early colonization of plants in an area is influenced mostly by climatic, edaphic and phytogeographic factors. As arbuscular mycorrhizae (AM) was associated with early invasion of land plants on earth, AM may have some role in defining the first seral community in any land. Two riverbanks were selected to study their pioneer plant community structure with species composition and diversity, soil characters and arbuscular mycorrhizal association; and correlations among these factors. Species composition, diversity and richness indices, active AM association of early colonizing plant species, soil texture, moisture, $\mathrm{pH}$ and E.C in two river banks differed. Similarity index for plant species between the two communities was poor. Diversity and richness indices were high in $\mathrm{K}$ site while evenness was high in R site. AM colonization and spore density correlated highly with plant cover and frequency in both riverbanks. Soil moisture showed a strong negative impact on mycorrhization, soil organic carbon showed little. Soil pH showed varied correlation in different sites. Early colonizing plants in $\mathrm{R}$ site with silt-loam soil with high moisture level are found poorly mycotrophic or nonmycotrophic; though plant cover correlated highly with mycotrophy in both sites. Plants in sandy soil of $\mathrm{K}$ site are highly mycotrophic and with high arbuscular and vesicular colonizations. The distribution of frequency in $\mathrm{R}$ site is highly deviated from Raunkiuer's frequency class; in K site it is rather stable. The soil condition is only key factor to determine plant composition and plantmycorrhizal relations influencing colonization of early seral community.
\end{abstract}

Keywords: AM spore density; Diversity index; Frequency; Similarity index; Mycorrhizal colonization.

\section{Introduction}

Succession of plant species in denuded land is influenced by a number of ecological factors of which climatic, edaphic factors and vegetation types of the adjacent region have a major role. Ecological habitat and plant 
characteristics, including positive or negative interactions among plants (Maestre et al., 2003) mainly maintain the coexistence of plant species (Tilman, 1988; Berendse, 1981). River banks or riverbeds harbor plant succession, often only first or second seral stages as the zones get inundated in every monsoon. The colonizers in first seral community also compete for establishment that may be favored by mycorrrizal association though they are also washed away with monsoon tides and have to advent and recolonise along with plant species.

As soil biota comprises most of the earth's biological stock and their diversity and play important role in ecosystem functioning (Fitter et al., 2005), they have influencing role in succession too. Among the soil microflora, the obligate endophyte, arbuscular mycorrhizal fungi (AMF) belonging Glomeromycota are widespread in natural ecosystems. They contribute to plant nutrition in absorbing less mobile nutrients especially phosphorus and micronutrients (Marschner and Dell, 1994); active mostly in nutrient limited (Liu et al., 2007) dry soil (Augé et al., 2016). AMF are beneficial to tropical plant species and ecosystems (Siqueira et al., 1998; Pasqualini et al., 2007; Zangaro et al., 2007). Their potential influence in enhancement of growth and biomass (Ghosh and Verma, 2006; Jha et al., 2012; Mayerhofer et al., 2013), plant nutrient content (Pasqualini et al., 2007), aggregation of soil particles and on plant diversity (Rillig, 2004) increased interest in AMF in recent years. Effects of AMF on plant-plant interactions though varied, Van Der Heidjen et al. (1998) and Van Der Heijden and Horton (2009) provided evidence that the mycorrhizal network ameliorate competition in natural ecosystems and diversity of AMF determines plant community structure as the response of each plant species vary to each AMF. AMF diversity is one of the major factor in maintaining plant biodiversity and ecosystem stability and function. Several studies showed that
AMF alters plant community structure by affecting the relative abundance and diversity of plant species (Gange et al., 1990; Sanders and Koide, 1994). AMF also affect plant community by the difference in growth responses of plant species to AM colonization, known as 'mycorrhizal dependency' (Plenchete et al., 1983). A study revealed that mycorrhizal fungi increase plant competition as mycorrhizal networks were found to amplify size inequality originated from intraspecific competition (Ayres et al., 2006).

Reports on the influence of Arbuscular mycorrhizae (AM) on coexistence of plant species in early seral community are less (Busby et al., 2011). Arbuscular mycorrhizae (AM) evolved with early land plants in Devonian period (Taylor et al., 1995). About $90 \%$ of total plants form symbiotic associations with AM. They are tolerant to a wide range of ecological conditions i.e. soil $\mathrm{pH}$, temperature, nutrient gradients etc. so they are active in most ecosystems including riverbank, seashore, disturbed or polluted area. Host plant, edaphic and environmental factors, soil nutrients (Howler et al., 1987) influence AM colonization, spore population and AM species composition (Antibus and Lesica, 1985). The network of external hyphae of AM can stabilize sand dunes, loams and disturbed soil (Tisdall, 1991). AM fungi play important role in maintaining and producing soil aggregates. The external mycelial networks entrap soil particles with a glycoprotein glomalin and produce water stable soil aggregates (Bedini et al., 2009). Dependency on AM also varies with plant species and plays a key role in formation of plant community structure in an area (Smith and Read, 2008). AM may play a role in establishment of plant species in land without vegetation in transition zones like sand dune or tidal belt.

We conducted the present study to assess the role of arbuscular mycorrhizae on early succession and establishment of plant species. The first 
seral plant community in the banks of two rivers, Kansabati and Rupnarayan at Midnapur and Kolaghat (60 km apart in W.B., India) was studied for their plant cover, community structure and AM association. The edaphic conditions of the two banks were also studied to understand the relation of plant community and AM association better.

\section{Materials and methods}

\section{Study site and sampling}

The study was conducted in bank of Kansabati River at Midnapur $\left(22.30^{\circ} \mathrm{N}\right.$ and $87.20^{\circ} \mathrm{E}$ ) and Rupnarayan River at Kolaghat $\left(22.31^{\circ} \mathrm{N}\right.$ and $\left.87.36^{\circ} \mathrm{E}\right)$ located in Midnapore District, West Bengal, India. The banks get inundated in each monsoon and bare from December to June. Here the dry summer (March to June) has an average temperature of 30 ${ }^{\circ} \mathrm{C}$ with a maximum of $42{ }^{\circ} \mathrm{C}$. In winter the average temperature is $18{ }^{\circ} \mathrm{C}\left(11^{\circ} \mathrm{C}\right.$ to $\left.26^{\circ} \mathrm{C}\right)$. Average rainfall is $110 \mathrm{~cm}(70$ $460 \mathrm{~cm}$ ). Most rainfall occurs within June to September. For plant vegetation study, 20 quadrates $\left(150 \mathrm{~cm}^{2}\right)$ were plotted at random from water level to $10 \mathrm{~m}$ upward the bank (land get drowned in monsoon) and up to 2,000 m length alongside in $\mathrm{K}$ and $\mathrm{R}$ site. Rhizospheric soil samples with intact root system of each species from each site were collected in triplicate in labeled polythene bags. Sampling was done in March.

\section{Ecological study}

Frequency of distribution was studied and classified according to Raunkiauer (1934). Basal cover of plants was calculated by foliage cover charted on graph. Species Equitability index and Richness index (Margalef, 1968); Shannon's Diversity Index (Shannon et al., 1963) was calculated. Similarity index of two sites were calculated as $\mathrm{S}=100 \mathrm{x}$ $2 \mathrm{C} /(\mathrm{a}+\mathrm{b}) ; \mathrm{S}_{\mathrm{J}}=\mathrm{a} / \mathrm{a}+\mathrm{b}+\mathrm{c}$ (Jaccard, 1912); $S_{s}=2 a / 2 a+a+b+c$ (Sørensen, 1948).

\section{Soil analyses}

Composite rhizospheric soil sample of each site was tested for particle size distribution (Buoycous, 1962), EC and soil NPK from soil analysis kit in triplicate and. Composite soil sample from each species of both sites was tested for $\mathrm{pH}$, moisture content (Jackson, 1973) and organic carbon content (Walkley and Black, 1934) in triplicate. Rhizospheric soil samples were air dried and preserved at $4{ }^{\circ} \mathrm{C}$ for further study of AM spore population.

\section{Mycorrhizal study}

Fine tertiary roots were collected immediately after collecting the root samples. Root samples were washed thoroughly, cut into $1 \mathrm{~cm}$ pieces and preserved in 50\% alcohol. For mycorrhizal analyses roots were treated with $10 \% \mathrm{KOH}$ solution at $90{ }^{\circ} \mathrm{C}$ for 45 min. Then neutralized with $1 \% \mathrm{HCl}$ and stained with $0.5 \%$ tryphan blue solution (Phillips and Hayman, 1970). AM colonization was calculated by the following formula: Colonisation $\%=$ Number of infected root pieces $(1 \mathrm{~cm}) \times$ $100 /$ Number of total root pieces.

Vesicular and arbuscular colonization was calculated according to this formula with presence of them in roots. AM spores were isolated following wet sieving and decanting technique (Gerdemann and Nicholson, 1963) using sieves of $710 \mu, 450 \mu, 300 \mu, 150 \mu$ and $53 \mu$ sieves in descending order. Spore density was calculated in $100 \mathrm{~g}$ air dried soil; spores identified according to the manual of Schenck and Perez (1987).

\section{Data analyses}

Data analyses were done by Excel and SPSS 10.

\section{Results}

Soil texture, E. C., range of $\mathrm{pH}$, moisture content and organic carbon 
content were differed in two riverbanks (Table 1, 2, 3). The soil texture in $\mathrm{K}$ bank is sandy loam with higher \% of coarse sand while silty loam in R bank (Table 1) (Brady, 1984). The range of $\mathrm{pH}$ was acidic to neutral in $\mathrm{K}$ bank; in $\mathrm{R}$ bank it was mainly acidic. EC was higher in $\mathrm{R}$ bank than K bank. Soil available NPK, especially phosphorus was very poor in both sites, slightly high in $\mathrm{R}$ site. Soil moisture and organic carbon content were higher in $\mathrm{R}$ bank than $\mathrm{K}$ bank but differed in each plant rhizophere (Table 2, 3).

Table 1. Soil texture in $\mathrm{K}$ bank is sandy loam with higher $\%$ of coarse sand while silty loam in $\mathrm{R}$ bank.

\begin{tabular}{|c|c|c|c|c|c|c|c|c|c|}
\hline \multirow{2}{*}{$\begin{array}{l}\text { River } \\
\text { site }\end{array}$} & \multicolumn{4}{|c|}{ Soil textute } & \multirow{2}{*}{$\begin{array}{c}\text { E.C } \\
\mathrm{me} / 100 \mathrm{~g}\end{array}$} & \multirow{2}{*}{$\begin{array}{c}\mathrm{pH} \\
\text { range }\end{array}$} & \multicolumn{3}{|c|}{ Available } \\
\hline & $\begin{array}{l}\text { Coarse } \\
\text { sand }\end{array}$ & $\begin{array}{c}\text { fine } \\
\text { sand }\end{array}$ & Silt & Clay & & & N \% & P\% & K\% \\
\hline $\mathrm{K}$ & $53 \%$ & $35 \%$ & $10 \%$ & $2 \%$ & $0.63 \pm 0.03$ & $5.6-7.2$ & 0.0048 & 0.0016 & 0.0040 \\
\hline $\mathrm{R}$ & $8 \%$ & $40 \%$ & $46 \%$ & $6 \%$ & $0.88+0.02$ & $5.5-6.3$ & 0.0067 & 0.0033 & 0.0047 \\
\hline
\end{tabular}

The first seral plant community species composition was also markedly varied in two sites (Table 2, 3; Figure 1). In $\mathrm{K}$ site total number of species was twenty of which twelve had mycorrhizal association; while in $\mathrm{R}$ site out of total eighteen species only five was mycorrhizal. Species composition was exclusive in two sites, only three species were common, Cyperus compressus L., Cyanotis axillaries Roem and Schut,
Alternanthera sessilis $\mathrm{R}$. Br. These three species showed higher cover, frequency and AM colonization $\%$ in $\mathrm{K}$ site. Vegetation cover was $83 \%$ more in $\mathrm{K}$ bank than $\mathrm{R}$ bank. Area covered by mycorrhizal species was higher (85\%) in $\mathrm{K}$ bank than $\mathrm{R}$ bank (60\%). In $\mathrm{R}$ bank, most of the plant species are aquatic or wetland species belong to nonmycotrophic families and showed colonization nil.

Table 2. Species composition, covered area, frequency, AM status and soil conditions in riverbank of Rupnarayan.

\begin{tabular}{|c|c|c|c|c|c|c|c|}
\hline Species & $\begin{array}{l}\text { Percentage } \\
\text { of area } \\
\text { covered }\end{array}$ & $\begin{array}{l}\text { Relative } \\
\text { frequency }\end{array}$ & $\begin{array}{c}\mathbf{A M} \\
\text { infection \% }\end{array}$ & $\begin{array}{l}\text { Spore density } \\
100 \text { g soil }\end{array}$ & soil pH & $\begin{array}{c}\text { Moisture } \\
\text { content of soil } \\
\%\end{array}$ & $\begin{array}{l}\text { Organic carbon } \\
\text { content of soil }\end{array}$ \\
\hline 1. Echornia crassipes Pers & 1.0 & 100 & - & - & 6.0 & 85 & 0.32 \\
\hline 2. jussia repens $\mathrm{L}$. & 0.22 & 60 & - & - & 5.8 & 81 & 0.30 \\
\hline 3. Cyperus compressus L. * & 0.16 & 60 & - & - & 5.7 & 79 & 1.53 \\
\hline 4. Cyperus rotundus $\mathrm{L}$. & 0.32 & 80 & - & - & 5.5 & 78 & 1.44 \\
\hline 5. Cyanotis axillaries Roem and Schut ${ }^{*}$ & 0.15 & 40 & - & . & 5.6 & 66 & 1.19 \\
\hline 6. Fimbristylis sqarrossus VahL. & 0.27 & 80 & - & - & 5.8 & 65 & 1.65 \\
\hline 7. Bacopa monieri & 0.4 & 40 & - & - & 6.0 & 60 & 1.3 \\
\hline 8. Eclipta alba Hassk & 0.3 & 60 & 24 & 36 & 6.0 & 60 & 1.6 \\
\hline 9. Eclipta prostrata Hassk & 0.25 & 60 & 18 & 27 & 6.0 & 61 & 1.24 \\
\hline 10. Scirpus mucronatus L. & 0.34 & 80 & - & - & 5.7 & 52 & 1.14 \\
\hline 11. Ipomea biloba & 0.32 & 60 & - & - & 6.0 & 46 & 0.66 \\
\hline 12. Oldenlandia brachatya Wight. & 0.18 & 40 & - & - & 6.0 & 36 & 0.60 \\
\hline 13. Kylling a triceps Rottb. & 0.26 & 60 & - & - & 5.5 & 38 & 0.80 \\
\hline 14. Solanum nigram L. & 0.36 & 50 & 06 & 17 & 6.0 & 28 & 0.96 \\
\hline 15. Lantana camara $\mathrm{L}$ & 1.6 & 60 & 32 & 62 & 6.0 & 20 & 0.90 \\
\hline 16. Alternanthera sessilis R. Br. ${ }^{*}$ & 0.26 & 60 & - & - & 5.6 & 45 & 0.60 \\
\hline 17. Parthenium argentatum & 3.0 & 100 & 58 & 120 & 6.1 & 22 & 0.91 \\
\hline 18. Croton bonplandianum Bal. & 1.2 & 80 & 32 & 69 & 6.2 & 18 & 0.88 \\
\hline
\end{tabular}

* Species common in both sites. 
Table 3. Species composition, percentage of covered area, frequency, AM colonisation and spore density and soil conditions in riverbank of Kansabati.

\begin{tabular}{|c|c|c|c|c|c|c|c|}
\hline Species & $\begin{array}{l}\text { Percentage of } \\
\text { area covered }\end{array}$ & $\begin{array}{l}\text { Relative } \\
\text { Frequency }\end{array}$ & $\begin{array}{c}\text { AM } \\
\text { Infectio } \\
\mathbf{n} \\
\%\end{array}$ & $\begin{array}{c}\text { Spore } \\
\text { density } \\
/ 100 \mathrm{~g} \\
\text { soil }\end{array}$ & $\begin{array}{l}\text { Soil } \\
\text { pH }\end{array}$ & $\begin{array}{l}\text { Moisture } \\
\text { content of } \\
\text { soil } \%\end{array}$ & $\begin{array}{l}\text { Organic } \\
\text { carbon }\end{array}$ \\
\hline 1. Polygonum hydropiper $\mathrm{L}$. & 0.22 & 60 & - & - & 7.1 & 79 & 0.23 \\
\hline 2. P. plebejum var. micranthema $\mathrm{R}$. Br. & 0.20 & 60 & - & - & 7.0 & 79 & 0.26 \\
\hline 3. Cyanotis axillaries Roem and Schut. * & 0.17 & 20 & - & - & 6.3 & 75 & 1.03 \\
\hline 4. Cyperus compressus L. * & 0.20 & 40 & & - & 6.6 & 70 & 0.63 \\
\hline 5. C. amabilis.Vahl. & 0.33 & 80 & 04 & - & 6.0 & 63 & 0.73 \\
\hline 6. C. castpidatus $\mathrm{H}$. B. and $\mathrm{K}$. & 0.28 & 80 & 12 & 10 & 5.6 & 62 & 0.70 \\
\hline 7. Bulbostylis barbata Kuth. & 0.27 & 100 & 14 & 25 & 6.0 & 60 & 0.70 \\
\hline 8. Mariscus squarosus Carke. & 0.25 & 100 & 24 & 55 & 5.7 & 60 & 0.68 \\
\hline 9. Fimbristylis monostachya Hassk. & 0.63 & 100 & - & - & 7.0 & 71 & 0.80 \\
\hline 10. Anielema nudiflorum $\mathrm{R}$. Br. & 0.16 & 20 & - & - & 6.4 & 71 & 1.03 \\
\hline 11. Alternanthera sessilis R. Br. ${ }^{*}$ & 0.6 & 60 & - & - & 6.2 & 53 & 0.40 \\
\hline 12. Jussia sufruiticosa Hassk. & 0.24 & 100 & - & - & 7.0 & 52 & 1.30 \\
\hline 13. Paspellum scobriculatum $\mathrm{L}$. & 1.80 & 100 & 48 & 128 & 6.4 & 42 & 0.76 \\
\hline 14. Mimulus gracilis $\mathrm{R}$. Br. & 0.32 & 100 & 40 & 126 & 6.3 & 42 & 0.76 \\
\hline 15. Echinochloa polystachya H. B. \& K. & 1.02 & 100 & 36 & 110 & 6.1 & 36 & 1.2 \\
\hline 16. Saccharum officinarum L. & 5.10 & 100 & 32 & 62 & 5.8 & 32 & 0.46 \\
\hline 17. Cynodon dactylon Pers. & 2.10 & 100 & 32 & 60 & 5.6 & 20 & 0.44 \\
\hline 18. Llindenbergia polyantha Royle & 0.38 & 80 & 27 & 43 & 6.5 & 32 & 1.50 \\
\hline 19. Limnophila conferta Benth. & 0.36 & 80 & 28 & 46 & 6.5 & 30 & 1.53 \\
\hline 20. Aristida redacta Stapf. & 1.2 & 100 & 44 & 96 & 5.6 & 16 & 0.36 \\
\hline
\end{tabular}

* Species common in both sites.

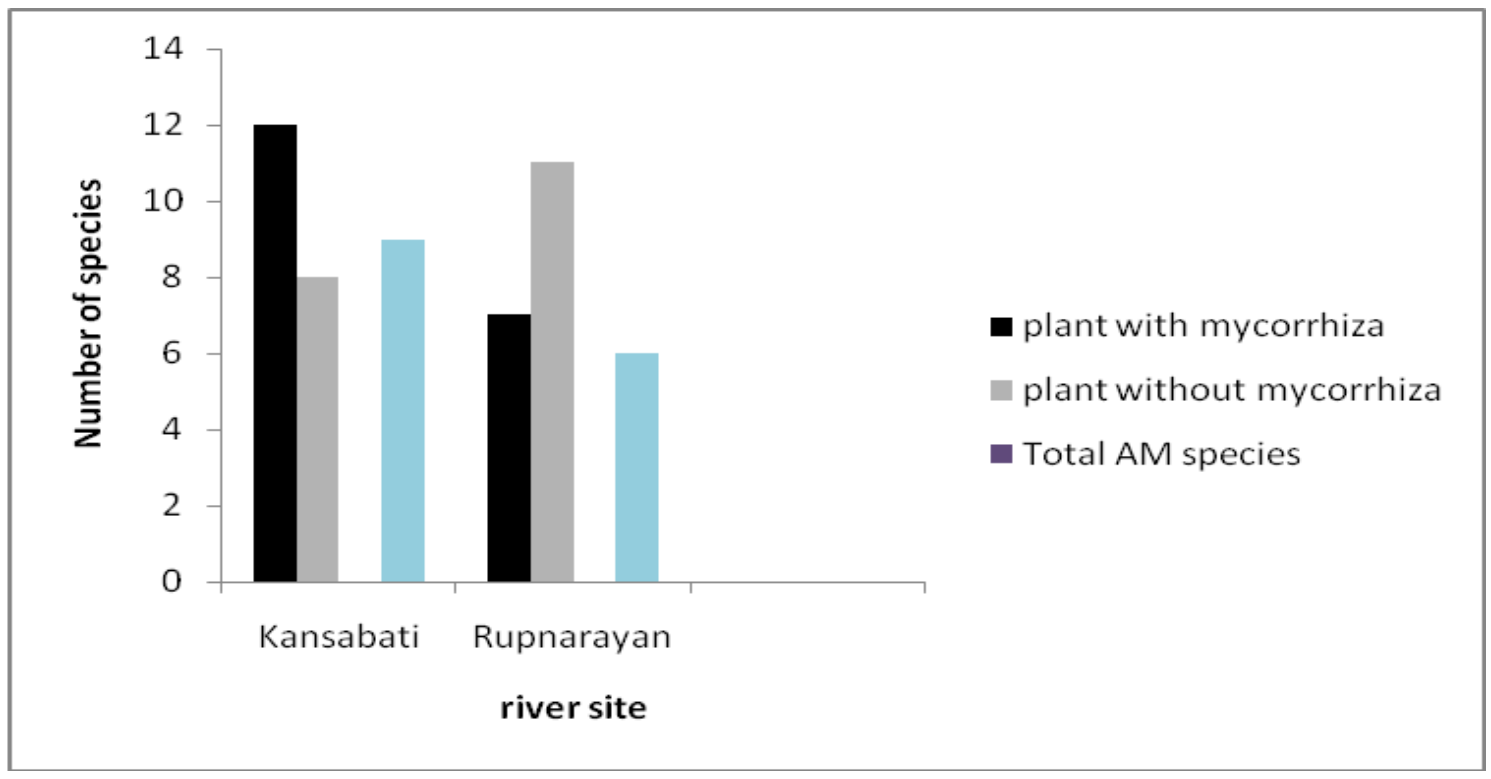

Figure 1. Number of mycorrhizal and non- mycorrhizal plant species in river banks of Kansabati and Rupnarayan

Some of the accepted nonmycorrhizal species belonging to the Family Cyperaceae, C.amabilis, C. cuspidatus, Bulbostylis barbata and Mariscus squarrosus showed mycotrophy with vesicle and arbuscle in $\mathrm{K}$ site. In $\mathrm{R}$ bank $50 \%$ plant species are aquatic or semi-aquatic growing in soil with moisture level $>63 \%$. In $\mathrm{K}$ bank, $35 \%$ are wetland species, rest of the vegetation grew within $16 \%$ to $63 \%$ soil moisture level; though plants growing in $>63 \%$ moisture showed better AM colonization in $\mathrm{K}$ site. Similarity indices within the two pioneer communities were very poor (Table 4). The species richness 
index and diversity indices were higher in $\mathrm{K}$ site, while species evenness was higher in $\mathrm{R}$ site. Richness of mycotrophic species was more in $\mathrm{K}(60 \%)$ bank than
R bank (33.6\%) (Figure 1). Plant species with arbuscular and vesicular colonization was higher in $\mathrm{K}$ site (Figure 2).

Table 4. Equitability, Richness, Similarity Indices of the two communities.

\begin{tabular}{|c|c|c|c|c|c|c|}
\hline & Equtability & Richness & Shannon's & \multicolumn{3}{|c|}{ Similarity Index } \\
\cline { 7 - 8 } & Index & Index & Diversity Index & Jaccard's & Sørensen's & Czechovski \\
\hline Kansabati & 1.82 & 7.0 & 3.321 & 0.0857 & 0.1463 & 0.1071 \\
\hline Rupnarayan & 2.21 & 6.55 & 2.886 & 0.085 & \\
\hline
\end{tabular}

\section{Frequency class}

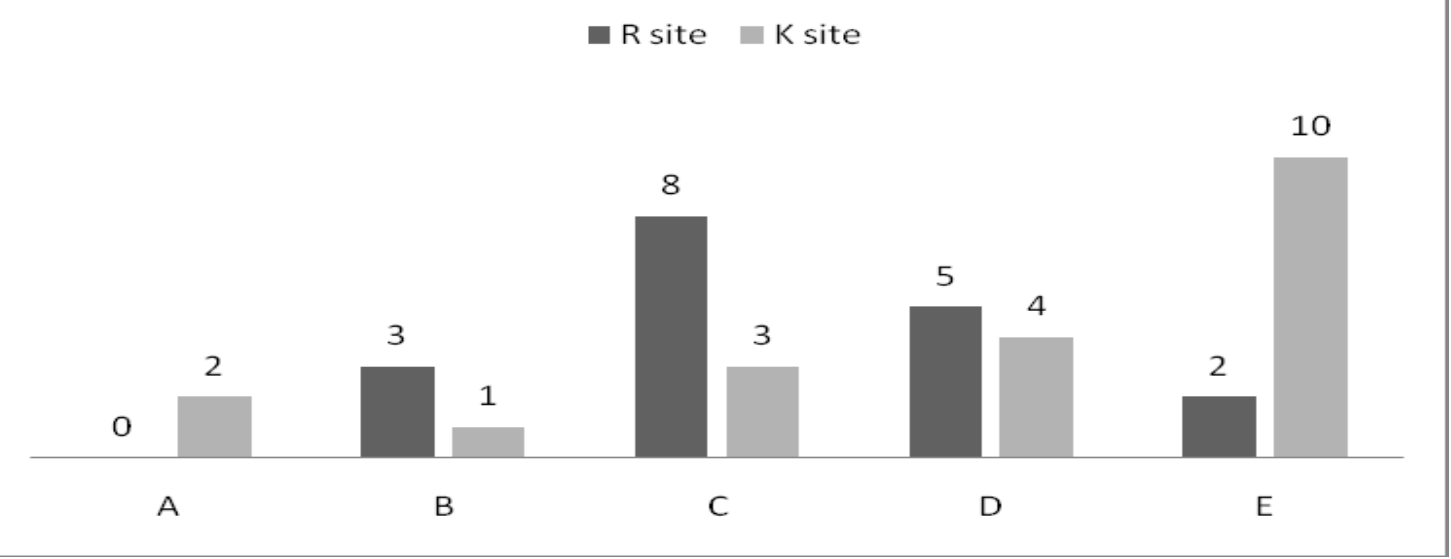

Figure 3. Distribution of frequency class in two communities.

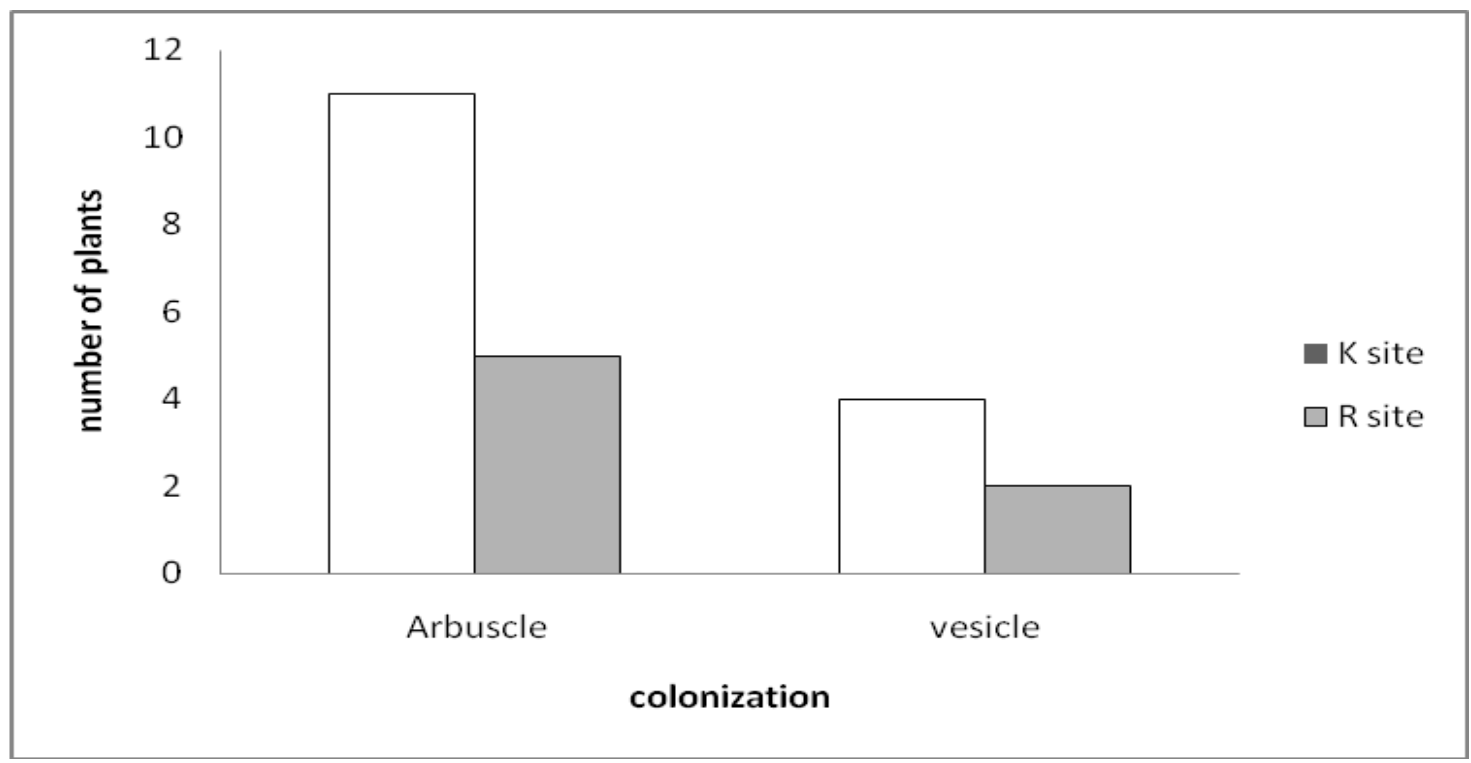

Figure 2. Arbuscular and vesicular colonization \% in plants of two river banks vegetation. 
Distribution of frequency class was near to Raunkiaer $(\mathrm{A}>\mathrm{B}>\mathrm{C}</=/>$ $\mathrm{D}<\mathrm{E})$ in $\mathrm{K}$ site $(\mathrm{A}>\mathrm{B}<\mathrm{C}<\mathrm{D}<\mathrm{E})$ while it was highly deviated in $\mathrm{R}$ site $(\mathrm{A}<\mathrm{B}<\mathrm{C}<$ $\mathrm{D}>\mathrm{E}$ ) (Figure 3). Absence of $\mathrm{A}$ and highest $\mathrm{C}, \mathrm{E}<\mathrm{D}$ indicates highly unstable and disturbed community. Maximum species in $\mathrm{E}$ in the former indicates rapid transformation tendency to next seral community in more stable form. Relative frequency showed significantly high positive correlation with AM colonization and spore density in $\mathrm{K}$ site (Table 5 ). In $\mathrm{R}$ site relative frequency is in significant positive correlation with AM colonization; positive but not significant with spore density. Plant cover showed significantly high positive correlation with AM colonization and spore density in $\mathrm{R}$ site while in $\mathrm{K}$ site in significant positive correlation with AM colonization; positive but not significant with spore density. AM colonization and spore density showed significant positive correlation with soil $\mathrm{pH}$ in $\mathrm{R}$ site while significant negative correlation in $\mathrm{K}$ site. Soil moisture content was observed with significant negative correlation with mycotrophy in both sites. Soil organic matter and mycorrhizal association showed insignificant positive correlation.

Table 5. Pearson's coefficient correlation between AM colonisation and spore density and covered area, soil conditions in riverbank of Kansabati and Rupnarayan.

\begin{tabular}{|l|cccccc|}
\hline Riverbanks & Colonization \% & $\begin{array}{c}\text { \% area } \\
\text { covered }\end{array}$ & $\begin{array}{c}\text { Relative } \\
\text { frequency }\end{array}$ & Soil pH & $\begin{array}{c}\text { Soil } \\
\text { moisture } \\
\text { content }\end{array}$ & $\begin{array}{c}\text { Soil } \\
\text { organic } \\
\text { content }\end{array}$ \\
\hline \multirow{2}{*}{ Kansabati } & Spore density & 0.43 & $0.92^{*}$ & $-0.51^{*}$ & $-0.83^{*}$ & 0.09 \\
& Colonization \% & $0.81^{*}$ & $0.50^{*}$ & -0.39 & $-0.71^{*}$ & 0.06 \\
\hline \multirow{2}{*}{ Rupnarayan } & Spore density & $0.82^{*}$ & 0.43 & $0.59^{*}$ & $-0.59^{+}$ & 0.05 \\
& & & & & $-0.63^{*}$ & 0.1 \\
\hline
\end{tabular}

* Significant at $\mathrm{P}<0.05$.

\section{Discussion}

Though under same climate and phyto-geography, the soil properties of the two sites differed for the nature of rivers, and some of the soil properties have influenced the pioneer vegetation and their mycotrophy in two sites. The soil texture, $\mathrm{pH}$, moisture specially had a role in selection of both plant and fungal species. The major differences between the two communities are in frequency class distribution, species diversity, plant cover, richness and equitability indices. Plant cover, frequency, poor similarity indices are directly related to mycotrphy. In previous study positive correlation within host and fungus was found to increase plant diversity in a community
(Zang et al., 2014); here, though correlation is positive in both cases, plant composition of two sites varied much. In same phosphorus gradient plants differed in colonization pattern that was contrary to findings of Gosling et al. (2013) and following the concept of plant preference of Van Der Heijden et al. (1998).

Comparatively high silt, EC, moisture and NPK (slightly) in soil of R site may have favored more wetland non mycorrhizal plant species. The AM community also differed in the sites. According to Collins and Foster (2009), phosphorus gradient select the AM microflora, as the gradient here not differ more; other soil characters may also be responsible. But mycorrhization is 
strongly correlated with plant cover and frequency of species that undoubtedly strengthen the essential role of mycorrhizae in establishment of plant species in pioneer community.

Plants in wet soil have least tendency to associate with AM. Terrestrial species showing colonization percentage poor or zero ( $O$. brachiata) in this wet soil was found highly mycotrophic growing in dry land in previous study (Ghosh and Verma, 2000). Parthenium show intensive colonization and sporulation in most types of soil condition that is possible cause of its widespread distribution. Excessive moisture and easy supply of nutrients in this soil may also have reduced the mycorrhizal dependency along with colonization in host plants. As predicted by the functional equilibrium model (Johnson et al., 2003), in soils with sufficient phosphorous, relative allocation to arbuscules and extraradical hyphae generally reduced by nitrogen enrichment.

AMF distribution is patchy in wetlands over small spatial scales (Wolfe et al., 2007) and they are also found important drivers of plant community in such soils (Wolfe et al., 2006) in this study. As AM are obligate symbionts they can never survive without host plants. The riverbank soil is naturally low in AM propagules and obtained through runoff waters only. Though AM colonization is naturally poor in wetland, recent studies showed marshland species dominance depends on AM (Zhang et al., 2014).

In $\mathrm{K}$ site with less moisture and sandy soil, vegetation is dominated by grasses which showed high colonization $\%$ and spore density too. Grasses are generally dominating early colonizer in sandy soils. The fibrous root system promotes AM association and production of spores; that act as sources of inocula to infect other plants rapidly. Though maximum dominance was by Saccharum officicnarum but maximum colonization and spore density was found in Aristida redacta. S. officicnarum has long penetrating roots and is an indicator of underground water. As A. redacta is the first colonizer of this loose dry soil probably so more dependent on AM for procuring nutrients and retention of moisture. Species with fibrous root system are capable to form soil aggregates are pioneers and dominant in early seral community in sand dunes (Piotrowisky et al., 2004). The fibrous root system also helps to increase spore density, thus good source for AM inocila in AM deficient soil. Sedges are also early colonizer in low nutrient moist soil; they are naturally non mycorrhizal, if mycorrhizal with very low and mainly with mycelial colonization. In this study also sedges are mostly non mycorrhizal except four species from K site. Ragupati and Mahadevan (2000) reported these species as non-mycorrhizal but Ghosh and Verma (2000) found Bulbostylis barbata and Mariscus squarrosus highly mycorrhizal in natural vegetation and here also these species form vesicle and arbuscle. Formation of arbuscle points indicates active AM symbioses (Cooke et al., 1993). The comparative lower $\mathrm{pH}$ in drier parts also increased colonization as AM favor nutrient poor acidic soil (Davies et al., 1983). Low fertility of soil especially phosphate deficiency encourages mycorrhizal colonization in general (Mosse, 1973). However, Bethlenfalvay et al. (1988) suggested that root colonization is increased in drought stressed plants because of low phosphorus in soil and AM association is more needed for phosphorus uptake. Mycorrhizal benefit is usually greater when plants are P (Jin et al., 2016) for growth and biomass enhancement of host. Relatively poor availability of phosphorus in $\mathrm{K}$ site than $\mathrm{R}$ site may have negatively influenced in colonization but not dependency as predicted from correlations in $\mathrm{R}$ site.

In $\mathrm{R}$ site soil AM spores of six different species of Glomus only was found with diameter range - 30-310 $\mu \mathrm{m}$, dominated by. $G$. intraradices and G. microaggregatum. $\mathrm{K}$ site contained 
only three Glomus species, Glomus fasciculatum, G.deserticola and G. microaggregatum along with Acaulospora scobriculata, A. spinosa, A. bireticulata, Scutellospora nigra and two Gigaspora species; total nine AMF. It should be noted that these AMF species also succeeds with plants in the few months as the sites get inundated every year. So these plants or total ecosystem have a choice for these AMFs too. Plant species vary in the degree of response to AMF species has important implications for growth of individual plant species (Ghosh and Verma, 2006). In turn, this will affect a plant's ability to coexist with other plant species in a community, Species composition of arbuscular mycorrhizal community has potential to control plant population and plant community (Van der Heijden et al., 1998; Van Der Heijden and Horton, 2009). Again, established mycorrhizal plant roots serve as important sources of inocula for initial nonmycorrhizal species, which may influence regeneration and contribute to patchy distributions of species within the community (Koide and Dickie, 2002). In wet soil the dominant plant species are predicted to support growth and survival of subdominant initial nonmycorrhizal species by providing mycorrhizal inocula (Mukherjee and Mandeep, 1998). According to Klironomos (2000), arbuscular mycorrhizae influence on the relationship between plant diversity and productivity that in the presence of AMF, productivity will saturate at lower levels of species richness because AMF increase the ability of plant species to utilize nutrient resources. On the contrary, Plant communities can also affect diversity and community composition of AMF (Johnson et al., 2004).

The soil texture is found also a factor to select AM and plant community both. Soil texture have role as hyphal network need soil porosity that is less in silt-loam soil. Such changes are important because they suggest an alteration in mycorrhizal functioning that, in turn, may impact plant community composition and ecosystem function. Dependency on AM decides the competitive ability and relationship among species in a plant community especially in nutrient poor soils. AM colonization enhances the photosynthetic efficacy and allocation of photosynthates in biomass and reproduction proper way (Goicoechea et al., 2014); specially, reduction of rootshoot ratio channeling more to above ground biomass production (Veresoglou et al., 2012). AM association of plants also modify the rhizospheric bacterial community, inviting a lot beneficial and mycorrhiza helper bacteria and act synergistically in nutrient cycling (Marschner and Timonen, 2005). Though AM dependency can never be calculated with prescribed formulas in natural habitat, active colonization is evidenced from arbuscular colonizations. Thus dependency on AM of pioneer community may enhance the nutrient cycling and productivity that may define structure and stability of this community and of next seral communities. Early colonizers with high dependency thus can alter the species composition and interaction.

\section{Conclusion}

Plant composition and diversity indices were found influenced by both edaphic conditions and AM mycotrophy in two sites. AM communities in two sites also were influenced by edaphic conditions. AM colonization pattern differed. But plant cover or dominance was directly correlated with AM mycotrphy in both sites.

\section{Acknowledgement}

We are thankful to United Grants Commission (UGC), India for financial support. 


\section{Conflict of interest}

Authors declare that they have no conflicts of interests.

\section{References}

Antibus, R. K.; Lesica, P. C. Effects of soil parent material on mycorrhizal infection of Alpine plants. In: Molina, R. (Ed.). NAOCM 85, Sixth North American Conference on Mycorrhiza. Cornvalis: Forest Research Laboratory, 1985.

Augé, R. M.; Toler, H. D.; Saxton, A. M. Mycorrhizal stimulation of leaf gas exchange in relation to root colonization, shoot size, leaf phosphorus and nitrogen: A quantitative analysis of the literature using metaregression front. Frontiers in Plant Science, v. 7, 2016. https://doi.org/10.3389/fpls. 2016.01084

Ayres, R. L.; Gange, A. C.; Aplin, D. M. Interactions between arbuscular mycorrhizal fungi and intraspecific competition affect size, and size inequality of Plantago lanceolata L. Journal of Ecology, v. 94, no. 2, p. 285-294, 2006. https://doi.org/10.1111/ j.1365-2745.2006.01103.x

Bedini, S.; Pellegrino, E.; Avio, L.; Pellegrino, S.; Bazoffi, P.; Argese, E.; Giovannetti, M. Changes in soil aggregation and glomalinrelated soil protein content as affected by the arbuscular mycorrhizal fungal species Glomus mosseae and Glomus intraradices. Soil Biology and Biochemistry, v. 41, no. 7, p. 1491-1496, 2009. https://doi.org/ 10.1016/j.soilbio.2009.04.005

Berendse, F. Competition between plantpopulations with differentrooting depths. 2 . Pot experiments. Oecologia, v. 48, p. 334-341, 1981. https://doi.org/10.1007/ BF00346491

Bethlenfalvay, G. J.; Brown, M. S.; Ames, R. N.; Thomas, R. S. Effects of drought on host and endophyte development in mycorrhizal soyabeans in relation to water use and phosphate uptake. Physiologia Plantarum, v. 72, no. 3, p. 565-571, 1988. https://doi.org/10.1111/j.1399-3054.1988. tb09166.x

Bouyoucos, G.J. Hydrometer method improved for making particle size analysis of soils. Agronomy Journal, v. 54, no. 5, p. 464-
465, 1962. https://doi.org/10.2134/agronj $1962.00021962005400050028 x$

Brady, N.C. (Ed.). The nature and properties of soils. 10. ed. New Delhi: Prentice Hall, 2002.

Busby, R. R.; Gebhart, D. L.; Stromberger, M. E.; Meiman, P. J.; Paschk, M. W. Early seral plant species' interactions with an arbuscular mycorrhizal fungi community are highly variable. Applied Soil Ecology, v. 48, no. 3, p. 257-262, 2011. https://doi.org/10.1016/ j.apsoil.2011.04.014

Collins, C. D.; Foster, B. L. Community-level consequences of mycorrhizae depend on phosphorus availability. Ecology, v. 90, no. 9, p. 2567-2576, 2009. https://doi.org/ 10.1890/08-1560.1

Cooke, M. A.; Widden, P.; O’Halloran, I. Development of vesicular arbuscular mycorrhiza in sugar maple (Acer saccharum) and effects of base cation amendment on vesicle and arbuscule formation. Canadian Journal of Botany, v. 71, no. 11, p. 14211426, 1993. https://doi.org/10.1139/b93171

Davies, E. A.; Young, J. L.; Linderman, R. G. Soil lime level $(\mathrm{pH})$ and VA-mycorrhizal fungal hyphae and structural stability of soil. Australian Journal of Soil Research, v. 9, p. 729-743, 1983.

Fitter, A. H.; Gilligan, C.; Hollingworth A.; Kleczkowski, A.; Twyman, R. M. Pitchford, J. W. Biodiversity and ecosystem function in soil. Functional Ecology, v. 19, no. 3, p. 369377, 2005. https://doi.org/10.1111/j.02698463.2005.00969.x

Gange, A. C.; Brown, V. K.; Farmer, L. M. A test of mycorrhizal benefit in an early successional plant coumnity. New Phytologist, v. 115, no. 1, p. 85-91, 1990. https://doi.org/10.1111/j.1469-8137.1990. tb00925.x

Gerdemann, J. W.; Nicolson, T. H. Spores of mycorrhizal Endogone species extracted from soil by wet-sieving and decanting. Transactions of the British Mycological Society, v. 46, no. 2, p. 235-244, 1963. https://doi.org/10.1016/S0007-1536(63) 80079-0

Ghosh, S.; Verma, N. K. A preliminary report on VA mycorrhizal status of some common weeds, trees and aquatic plants of South 
West Bengal. Science and Culture, v. 68, no. 5/6, p. 155-157, 2000.

Ghosh, S.; Verma, N. K. Growth and mycorrhizal dependency of Acacia mangium Willd inoculated with three vesicular arbuscular mycorrhizal fungi in lateritic soil. New Forests, 31:75, 2006. https://doi.org/ 10.1007/s11056-004-4763-7

Goicoechea, N.; Baslam, M.; Erice, G.; Irigoyen, J. J. Increased photosynthetic acclimation in alfalfa associated with arbuscular mycorrhizal fungi (AMF) and cultivated in greenhouse under elevated $\mathrm{CO}_{2}$. Journal of Plant Physiology, v. 171 , no. 18 , p. 17741781, 2014. https://doi.org/10.1016/j.jplph. 2014.07.027

Gosling, P.; Mead, A.; Proctor M.; Hammond, J.P.; Bending G. D. Contrasting arbuscular mycorrhizal communities colonizing different host plants show a similar response to a soil phosphorus concentration gradient. New Phytologist, v. 198, p. 546-556, 2013. https://doi.org/10.1111/nph.12169

Howeler, R. H.; Sieverding, E.; Saif, S. Practical aspect of mycorrhizal technology in some tropical crops and pastures. Plant and Soil, v. 100, no. $1 / 3, \quad$ p. 249-283, 1987. https://doi.org/10.1007/BF02370945

Jaccard, P. The distribution of the flora in the alpine zone. New Phytologist, v. 11, no. 2, p. 37-50, 1912. https://doi.org/10.1111/ j.1469-8137.1912.tb05611.x

Jackson, M. L. (Ed.). Soil chemical analyses. New Delhi: Prentice-Hall, 1973.

Jha, A.; Kumar, A.; Saxena, R. A.; Kamalvanshi, M.; Chakravarty, N. Effect of arbuscular mycorrhizal inoculations on seedling growth and biomass productivity of two bamboo species. Indian Jornal of Microbiology, v. 52, no. 2, p.281-285, 2012. https://doi.org/10.1007/s12088-011-0213-3

Jin, Y.; Liu, H.; Luo, D.; Yu, N.; Dong, W.; Wang, C.; Zhang, X.; Dai, H.; Yang, J.; Wang, E. DELLA proteins are common components of symbiotic rhizobial and mycorrhizal signalling pathways. Nature Communication, v. 7, Article number, p. 12433, 2016. https://doi.org/10.1038/ ncomms12433

Johnson, D.; Vandenkoornhuyse, P. J.; Leake, R.; Gilbert, L. A.; Booth, R. E.; Grime, J. P.; Young, J. P. W.; Read, D. J. Plant communities affect arbuscular mycorrhizal fungal diversity and community composition in grassland microcosms. New Phytologist, v. 161 , p. 503-515, 2004. https://doi.org/ 10.1046/j.1469-8137.2003.00938.x

Johnson, N. C.; Rowland, D. L.; Corkidi, L.; Egerton, L.; Warburton, M.; Allen, E. B. Nitrogen enrichment alters mycorrhizal allocation at five mesic to semiarid grasslands. Ecology, v. 84, no. 7, p. 18951908, 2003. https://doi.org/10.1890/00129658(2003)084[1895:NEAMAA]2.0.CO;2

Johnson, N. C.; Tilman, D.; Wedin, D. Plant and soil controls on mycorrhizal fungal communities. Ecology, v. 73, no. 6, p. 20342042, 1992. https://doi.org/10.2307/ 1941453

Klironomos, J. N.; McCune, J.; Hart, M.; Nevill, J. The influence of arbuscular mycorrhizae on the relationship between plant diversity and productivity. Ecology Letters, v. 3, no. 2, p. 137-141, 2000. https://doi.org/10.1046/ j.1461-0248.2000.00131.x

Koide, R. T.; Dickie, I. A. Effects of mycorrhizal fungi on plant populations. Plant and Soil, v. $244, \quad$ no. $1 / 2, \quad$ p. $307-317,2002$. https://doi.org/10.1023/A:1020204004844

Liu, A.; Plenchette, C.; Hamel, C. Soil nutrient and water providers: How arbuscular mycorrhizal mycelia support plant performance in a resource-limited world. In: Hamel, C.; Plenchette, C. (Eds.). Mycorrhizae in crop production. Binghamton, NY: Haworth Food \& Agricultural Products Press, 2007. p. 37-66.

Maestre, F. T.; Bautista, S.; Cortina, J. Positive, negative, and net effects in grass-shrub interactions in Mediterranean semiarid grasslands. Ecology, v. 84, p. 3186-3197, 2003. https://doi.org/10.1890/02-0635

Margalef, R. (Ed.). Perspectives in Ecological Theory. Chicago: University of Chicago Press, 1968.

Marschner, H.; Dell, B. Nutrient uptake in mycorrhizal symbiosis. Plant and Soil, 159:89, 1994. https://doi.org/10.1007/ BF00000098

Marschner, P.; Timonen, S. Interactions between plant species and mycorrhizal colonization on the bacterial community composition in the rhizosphere. Applied Soil 
Ecology, v. 28, no. 1, p. 23-36, 2005. https://doi.org/10.1016/j.apsoil.2004.06.007

Mayerhofer, M. S.; Kernaghan, G.; Harper, K. A. The effects of fungal root endophytes on plant growth. Mycorrhiza, v. 23, no. 2, p. 119-128, 2013. https://doi.org/10.1007/ s00572-012-0456-9

Mosse, B. Advances in the study of vesiculararbuscular mycirrhiza. Annual Review of Phytopathology, v. 11, p.171-196, 1973. https://doi.org/10.1146/annurev.py.11.090 173.001131

Mukerji, K. G.; Mandeep, K. Mycorrhizal relationship of wetlands and rivers associated plants. In: Majumdar, S. K.; Miller, E. W.; Brenner, F. J. (Eds.). Ecology of wetlands and associated systems. Easton: Pennsylvania Academy of Science, 1998. p. 240-257.

Nelson, C. E.; Safir, G. R. Increased drought resistance in onion plants by mycorrhizal infection. Planta, v. 154, no. 5, p. 407-413, 1982. https://doi.org/10.1007/BF01267807

Pasqualini, D.; Uhlmann, A.; Stürmer, S. L. Arbuscular mycorrhizal fungal communities influence growth and phosphorus concentration of woody plant species from the Atlantic rain forest in South Brazil. Forest Ecology and Management, v. 145, no. $1 / 3$, p. $148-155$, 2007. https://doi.org/ 10.1016/j.foreco.2007.04.024

Phillips, J. M.; Hayman, D. S. Improved procedure for clearing roots and staining parasitic vesicular-arbuscular mycorrhizal fungi for rapid assessment of infection. Transactions of the British Mycological Society, v. 55, no. 1, p. 158-161, IN16-IN18, $1970 . \quad$ https://doi.org/10.1016/S00071536(70)80110-3

Piotrowski, J. S.; Denich, T.; Klironomos, J. N.; Graham, J. M.; Rillig, M. C. The effects of arbuscular mycorrhizas on soil aggregation depend on the interaction between plant and fungal species. New Phytologist, v. 164, no. 2, p. 365-373, 2004. https://doi.org/ 10.1111/j.1469-8137.2004.01181.x

Plenchette, C. A.; Fortin, A.; Forlan, N. Growth response of several plant species to mycorrhiza in a soil of moderate P-fertility. I. Mycorrhizae aunder field conditions. Plant and Soil, v. 70, no. 2, p. 199-209, 1983. https://doi.org/10.1007/BF02374780
Propster, J. R.; Johnson, N. C. Uncoupling the effects of phosphorus and precipitation on arbuscular mycorrhizas in the Serengeti. Plant and Soil, v. 388 , no. $1 / 2$, p. 21-34, 2015. https://doi.org/10.1007/s11104-0142369-1

Ragupati, S.; Mahadevan, A. Distribution of vericular arbuscular mycorrhiza in the plants and rhizosphere soils of the tropical plains Tamilnadu, India. Mycorrhiza, v. 3, no. 3, p. 123-136, 1993. https://doi.org/10.1007/ BF00208920

Raunkiauer, C. (Ed.). The life forms of plants and statistical plant Geography. Oxford: Calerndon Press, 1934.

Rillig, M. C. Arbuscular mycorrhizae and terrestrial ecosystem processes. Ecology Letters, v. 7, no. 8, p. 740-754, 2004. https://doi.org/10.1111/j.1461-0248.2004. 00620.x

Sanders, I. R.; Koide, R. T. Nutrient acquisition and community structure in cooccuring mycortrophic and non-mycotrophic old-field annuals. Functional Ecology, v. 8, no. 1 , p. 77-84, 1994. https://doi.org/ $10.2307 / 2390114$

Schenck, N. C.; Perez, V. (Eds.). Mannual for identification of VA mycorrhizal fungi. Gainsville, USA: Synergistic, 1987.

Shannon, C. E. A mathematical theory of communication. The Bell System Technical Journal, v. 27, p. 379-423, 1948. https://doi.org/10.1002/j.1538-7305.1948. tb01338.x

Siqueira, J. O.; Carneiro, M. A. C.; Curi, N.; Rosado, S. C. S.; Davide, A. C. Mycorrhizal colonization and mycotrophic growth of native woody species as related to successional groups in Southeastern Brazil. Forest Ecology and Management, v. 107, no. $1 / 3$, p. 241-252, 1998. https://doi.org/ 10.1016/S0378-1127(97)00336-8

Smith, S. E.; Read, D. J. (Eds.). Mycorrhizal symbiosis. 3. ed. Cambridge, UK: Academic Press, 2008.

Sørense, T. A method of establishing groups of equal amplitude in plant sociology based on similarity of species and its application to analyses of the vegetation on Danish commons. Kongelige Danske Videnskabernes Selskab, v. 5, no. 4, p. 1-34, 1948. Available from: <http://www.royal 
academy.dk/Publications/High/295_Sørense n, Thorvald.pdf>. Accessed on: Apr. 22, 2019.

Taylor, T. N.; Emy, W.; Haas, H.; Kerp, H. Fossil arbuscular mycorrhizae from the early Devonian. Mycologia, v. 87, no. 4, p. 387-395, 1995. https://doi.org/10.2307/3760776

Tillman, D. The greening of green revolution. Nature, v. 396, p.211-212, 1998. https://doi.org/10.1038/24254

Tisdall, J. M. Fungal hyphae and structural stability of soil. Australian Journal of Soil Research, v. 29, no. 6, p. 729-743, 1991. https://doi.org/10.1071/SR9910729

Van Der Heijden, M. G. A.; Boller, G. A. T.; Wiemken, A.; Sanders, I. R. Different arbuscular mycorrhizal fungal species are potential determinants of plant community structure. Ecology, v. 79, p. 2082-2091, 1998. https://doi.org/10.1890/0012-9658(1998) 079[2082:DAMFSA]2.0.CO;2

Van Der Heijden, M. G. A.; Horton, T. R. Socialism in soil? The importance of mycorrhizal fungal networks for facilitation in natural ecosystems. Journal of Ecology, v. 97, no. 6, p. 1139-1150, 2009. https://doi.org/10.1111/j.1365-2745.2009. 01570.x

Veresoglou, S. D.; Menexes, G.; Rillig, M. C. Do arbuscular mycorrhizal fungi affect the allometric partition of host plant biomass to shoots and roots? A meta-analysis of studies from 1990 to 2010. Mycorrhiza, v. 22, p. 227-235, 2012. https://doi.org/10.1007/ s00572-011-0398-7
Walkley, A. J.; Black, I. A. Estimation of soil organic carbon by the chromic acid titration method. Soil Sciences, v. 37, p. 29-38, 1934.

Wolfe, B. E.; Mummey, D. L.; Rillig, M. C.; Klironomos, J. M. Small-scale heterogeneity of arbuscular mycorrhizal fuangal abundance and community composition in a wetland plant community. Mycorrhiza, v. 17, no. 3, p. 175-183, 2007. https://doi.org/10.1007/ s00572-006-0089-y

Wolfe, B. E.; Weishampel, P. A.; Klironomos, J. M. Arbuscular mycorrhizal fungi and water table affect wetland plant community composition. Journal of Ecology, v. 94, no. 5, p. 905-914, 2006. https://doi.org/10.1111/ j.1365-2745.2006.01160.x

Zangaro, W.; Nishidate, F. R.; Vandresen, J.; Andrade, G.; Nogueira, M. A. Root mycorrhizal colonization and plant responsiveness are related to root plasticity, soil fertility and successional status of native woody species in southern Brazil. Journal of Tropical Ecology, v. 23, no. 1, p. 53-62, 2007. https://doi.org/10.1017/S02664674060037 13

Zhang, Q.; Sun, Q.; Koide, R.T.; Peng, Z.; Zhou, J.; Gu, X.; Gao, X.; Yu, M. Arbuscular mycorrhizal fungal mediation of plant-plant interactions in a Marshland Plant Community. The Scientific World Journal, v. 48 , p. $2-11, \quad 2014$. https://doi.org/ $10.1155 / 2014 / 923610$ 